\title{
Effects of farmyard manure and tillage systems on soil physical properties and corn yield in central Iran
}

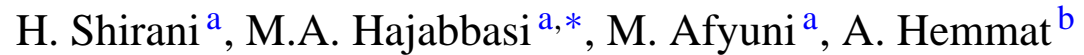 \\ ${ }^{a}$ Department of Soil Science, College of Agriculture, Isfahan University of Technology, Isfahan 84154, Iran \\ ${ }^{\mathrm{b}}$ Department of Farm Machinery, College of Agriculture, Isfahan University of Technology, Isfahan 84154, Iran
}

Received 20 March 2002; received in revised form 13 August 2002; accepted 21 August 2002

\begin{abstract}
Tillage management and manure application are among the important factors affecting soil physical properties and crop yield. A 2-year field experiment was conducted on a silty clay loam soil (fine-loamy, mixed, thermic Typic Haplargids). Effects of two tillage systems (moldboard plowing as conventional tillage $\left(T_{1}\right)$ and disk harrowing as reduced tillage $\left(T_{2}\right)$ ) at three farmyard manure rates (zero $\left(M_{1}\right), 30\left(M_{2}\right), 60\left(M_{3}\right) \mathrm{Mg} \mathrm{ha}^{-1}$ ) were studied on the soil physical properties and corn (Zea mays L.) yield. The experiment was carried out in split block design with three replications. Organic matter $(\mathrm{OM})$ content, bulk density (BD), saturated hydraulic conductivity $\left(K_{\mathrm{S}}\right)$, aggregate mean weight diameter (MWD) and dry biomass yield (DBY) were measured after harvesting in the second year. Manure application increased OM on both the row and inter-row tracks significantly. Manure application rate of $60 \mathrm{Mg} \mathrm{ha}^{-1}$ increased MWD $\left(0.33,0.40\right.$ and $0.75 \mathrm{~mm}$ for $M_{1}, M_{2}$ and $M_{3}$, respectively) at the $0-5 \mathrm{~cm}$ soil layer, but the effect was not significant below $5 \mathrm{~cm}$ depth. Adding manure significantly decreased soil BD on the row tracks $\left(1.39,1.22\right.$ and $1.17 \mathrm{Mg} \mathrm{m}^{-3}$ for $M_{1}, M_{2}$ and $M_{3}$ treatments, respectively), but did not have any significant effect on the inter-row tracks. Hydraulic conductivity was improved by manure applications both on the row and inter-row positions. Manure treatments $M_{2}$ and $M_{3}$ increased DBY compared to the $M_{1}$ treatment. Although moldboard plowing increased the depth of root penetration significantly ( $43 \mathrm{~cm}$ for $T_{1}$ and $30 \mathrm{~cm}$ for $T_{2}$ ), the effect of tillage systems on yield and soil physical properties was not significant.
\end{abstract}

(c) 2002 Elsevier Science B.V. All rights reserved.

Keywords: Farmyard manure; Moldboard plowing; Disk harrowing; Soil physical property; Corn

\section{Introduction}

Little research concerning the effects of organic amendments on soil physical properties are available in Iran. Although, information on the effect of animal manure and other organic fertilizers on crop yield are available, farmers in the region rely on chemical fertilizers to maintain crop yields, and pay little atten-

\footnotetext{
* Corresponding author. Tel.: +98-31-89-12-260; fax: +98-31-13-91-3470.

E-mail address: hajabbas@cc.iut.ac.ir (M.A. Hajabbasi).
}

tion to maintaining soil organic matter $(\mathrm{OM})$ in soils in Iran. Application of sewage sludge, compost, and cow manure at rates of 50 and $100 \mathrm{Mg} \mathrm{ha}^{-1}$ to the soil of this study resulted in a significant increase in aggregate mean weight diameter (MWD), available water content, saturation hydraulic conductivity, and infiltration rate, and a decrease on BD (Bahremand et al., 2003). Mosaddeghi et al. (2000) reported that application of manure to the soil counteracted soil compaction, and decreased soil compactibility. They also showed adding and mixing manure to the depth of $20 \mathrm{~cm}$, not only decreased compactibility and 
increased soil trafficability but also decreased subsoil compaction.

The impact of soil structure on controlling or modulating the distribution, flow and retention of water, solutes, gases and biota in agricultural and natural ecosystems is unquestioned (Qiguo and Hui, 2000). One of the modifiers of soil structure is tillage practice. Although soils are tilled basically to control weeds, the underlying goal of soil-manipulating activities, including tillage, is to stabilize and increase crop production (Unger, 1984). Conservation tillage systems have the potential to bring soil quality to a high stage and reduce soil loss by providing protective crop residue on soil surface and improving water conservation by decreasing evaporation losses (Unger and McCalla, 1980). Reduced tillage systems, however, lead to soil compaction, acidification, and concentration of nutrients and soil $\mathrm{OM}$ in the surface horizon. Continuous use of no-tillage system can cause measurable changes in soil mechanical, physical, chemical and biological properties (Unger, 1984).

The magnitude and trends of change in soil physical properties depend on antecedent conditions, wheel tracks, soil texture and climate (Lal, 1989). Contradicting results have been reported in literature about these effects. However, Lal et al. (1994) and Mahboubi et al. (1993) showed beneficial effects of long-term conservation tillage systems including chisel plowing and no-tillage compared to conventional tillage in ameliorating soil physical properties. No-tillage system resulted in lower BD and higher porosity and aggregation.

Soil structural improvement induced by incorporation of organic manure can partially help to prevent soil degradation (Thomas et al., 1996). Lack of tillage operations in a 20 -year old pasture resulted in a lower $\mathrm{BD}$ and a higher saturated hydraulic conductivity compared to similar land under continuous cultivation (Ellies (1986) cited in Soane (1990)). This may be due to the higher OM content and more stable structure in the under soil pasture.

There is little information on the effects of tillage, compaction, and organic manure addition to soil attributes in Iran. Arid soils in central Iran are intensively tilled, they are low in OM content and consequently have weak structural stabilities. Although Hajabbasi and Hemmat (2000) reported that in a clay loam soil in Isfahan, no-tillage system resulted in an increase in soil $\mathrm{OM}$ and thus larger aggregates. But no-tillage system could not compensate the adverse effects of heavy texture, very low OM $(0.1-0.5 \%)$ and an overall initial weak structure of the soil. Thus, Hemmat and Khashoei (1997), Hemmat and Taki (2001) and Mirlohi et al. (2000), reported that no-tillage systems in the arid regions of central Iran had an adverse effect on crop yields. The reason could be the heavy textured soil and low organic carbon, and an overall initial weak soil structure.

The objective of this study was to determine the effect of moldboard plowing and disk harrowing and farmyard manure on soil physical properties and corn biomass yield.

\section{Materials and methods}

\subsection{Study site}

This study was conducted at the Isfahan University of Technology research station farm $\left(32^{\circ} 32^{\prime} \mathrm{N}\right.$, $51^{\circ} 23^{\prime} \mathrm{E}$ ). The site has an arid climate and is $1630 \mathrm{~m}$ above sea level. Mean annual precipitation and temperature are $140 \mathrm{~mm}$ and $14.5^{\circ} \mathrm{C}$, respectively. The soil (fine-loamy, mixed, thermic Typic Haplargids) is formed on the alluvial sediments of Zayandehroud river initially low in $\mathrm{OM}(<0.5 \%)$, and with a history of intensive conventional tillage practices. The soil was fallowed 4 years prior to the start of this research. Soil properties prior to the experiment are shown in Table 1.

\subsection{Experimental procedures}

A split block design with two tillage systems and three farmyard manure rates with three replications was conducted for 2 years. The two tillage systems consisted of (a) moldboard plowing (with average

Table 1

Soil properties measured at different depths prior to the initiation of the experiment

\begin{tabular}{lllll}
\hline Depth $(\mathrm{cm})$ & Soil texture & $\mathrm{pH}$ & $\begin{array}{l}\mathrm{EC} \\
\left.(\mathrm{dS} \mathrm{m})^{-1}\right)\end{array}$ & $\begin{array}{l}\mathrm{OM} \\
\left(\mathrm{g} \mathrm{kg}^{-1}\right)\end{array}$ \\
\hline $0-15$ & Silty clay loam & 7.6 & 3.5 & 4.6 \\
$15-30$ & Silty clay loam & 7.5 & 2.8 & 3.6 \\
$30-50$ & Silty clay & 7.5 & 2.5 & 2.0 \\
\hline
\end{tabular}


Table 2

Chemical properties of farmyard manure applied to the soil

\begin{tabular}{lr}
\hline $\mathrm{N}(\%)$ & 32.2 \\
$\mathrm{P}(\%)$ & 17.5 \\
$\mathrm{~K}(\%)$ & 38.3 \\
$\mathrm{pH}$ & 7.4 \\
$\mathrm{EC}\left(\mathrm{dS} \mathrm{m}^{-1}\right)$ & 17.5 \\
$\mathrm{OM}\left(\mathrm{g} \mathrm{kg}^{-1}\right)$ & 62.3 \\
Dry density $\left(\mathrm{Mg} \mathrm{m}^{-3}\right)$ & 0.3 \\
\hline
\end{tabular}

depth of $30 \mathrm{~cm})+$ two shallow disk harrowings as conventional tillage and (b) disk harrowing (with average depth of $15 \mathrm{~cm}$ ) + two shallow disk harrowings as reduced tillage system. After tillage operations, decayed farmyard manure at rates of 0,30 , and $60 \mathrm{Mgha}^{-1}$ were uniformly applied on the surface and mixed to $15 \mathrm{~cm}$ depth by spade each year. Then, the field was ridged or transformed to the row and inter-row. Thus, greater manure along with the soil were accumulated on the row. Chemical properties of decayed farmyard manure are shown in Table 2. The blocks were separated by a $3 \mathrm{~m}$ spacing and plots $(5 \mathrm{~m} \times 10 \mathrm{~m})$ within the blocks were separated by a $2 \mathrm{~m}$ space. Corn (cultivar 704) was planted by hand on top of ridges with a row and seed spacing of 70 and $20 \mathrm{~cm}$, respectively. The tillage operation and manure application were performed in April of each year. One month after the manure application, the planting operation was carried out.

Furrow irrigation (common in the region) was applied at a flow rate of $1.41 \mathrm{~s}^{-1}$ at weekly intervals. For the second year similar treatments were applied to the same plots.

\subsection{Soil and crop yield measurements}

Soil physical properties and dry biomass yield (DBY) were only determined after harvesting of corn in the second year. Particle size distribution was determined using the hydrometer method (Sheldrick and Wang, 1993) in soil sample collected at 0-15, $15-30$ and $30-50 \mathrm{~cm}$ depths. Aggregate MWD of aggregates was determined by the wet sieving method of Kemper and Rosenau (1986) with a set of sieves of $2,1,0.5$, and $0.25 \mathrm{~mm}$ diameter was used. For determining MWD, soil samples were obtained on the rows from two depths of $0-5$ and $5-20 \mathrm{~cm}$. A hand spade was used to take the samples. For measur- ing saturated hydraulic conductivity $\left(K_{\mathrm{S}}\right)$ (Klute and Dirksen, 1986) and bulk density (BD), undisturbed core samples $(8 \mathrm{~cm}$ diameter and $7 \mathrm{~cm}$ height $)$ were collected from the row and inter-row positions at $0-10 \mathrm{~cm}$ depth. The standard core method was used for BD measurements. Soil hydraulic conductivity and BD were determined on separated samples. OM content was determined for samples collected on the row and inter-row positions at $0-5 \mathrm{~cm}$ depth (Walkley and Black, 1934). Two soil samples from the center of each plot were obtained for the measurement of each soil physical property at $2 \mathrm{~m}$ apart. Corn biomass from the center of each plot $\left(4 \mathrm{~m}^{2}\right)$ harvested by hand in October. DBY was measured using total dry shoot weight. Statistical analysis of the data was performed using SAS program (SAS, 1985).

\section{Results and discussion}

The effects of manure application on organic matter $(\mathrm{OM})$ content, $\mathrm{BD}$, saturated hydraulic conductivity $\left(K_{\mathrm{S}}\right)$, aggregate mean weight diameter (MWD) of soil, and DBY of corn were significant. However, tillage system and the interaction effects were not significant.

\subsection{Manure effect on soil OM}

Manure applications on this initially low OM soil significantly $(P<0.05)$ increased the content of soil OM after 2 years (Table 3 ). Manure application rates of 30 and $60 \mathrm{Mg} \mathrm{ha}^{-1}$ increased OM by threefold and fivefold for row tracks and twofold and fourfold for inter-row tracks, respectively. This result is in agreement with the study of Mosaddeghi et al. (2000) on the same soil. Meek et al. (1982) also reported that application of manure increased soil OM. Soil OM content on the row was significantly higher than the inter-row positions (22.7 and $16.6 \mathrm{~g} \mathrm{~kg}^{-1}$, respectively), due to accumulation of the manure on row tracks. This might be related to soil and manure movement into ridges' region during ridging operation of seedbed preparation.

\subsection{Manure effect on soil BD}

Manure applications significantly decreased BD on the row, but did not have any effect on the inter-row 
Table 3

Manure and tillage system effects on $\mathrm{BD}, K_{\mathrm{S}}$ (soil sampling depth was $0-10 \mathrm{~cm}$ ), OM (soil sampling depth was $0-5 \mathrm{~cm}$ ), MWD, DBY and root depth after harvesting of second year ${ }^{\mathrm{a}}$

\begin{tabular}{|c|c|c|c|c|c|c|c|c|c|c|}
\hline \multirow[t]{2}{*}{ Treatment } & \multicolumn{2}{|c|}{$\mathrm{BD}\left(\mathrm{Mg} \mathrm{m}^{-3}\right)^{\mathrm{b}}$} & \multicolumn{2}{|c|}{$K_{\mathrm{S}}\left(\mathrm{cm} \mathrm{h}^{-1}\right)^{\mathrm{c}}$} & \multicolumn{2}{|c|}{$\mathrm{OM}\left(\mathrm{g} \mathrm{kg}^{-1}\right)^{\mathrm{d}}$} & \multicolumn{2}{|c|}{$\operatorname{MWD}(\mathrm{mm})^{\mathrm{e}}$} & \multirow{2}{*}{$\begin{array}{l}\text { DSY } \\
\left(\mathrm{Mg} \mathrm{ha}^{-1}\right)^{\mathrm{f}}\end{array}$} & \multirow{2}{*}{$\begin{array}{l}\text { Root depth } \\
(\mathrm{cm})\end{array}$} \\
\hline & Row & Inter-row & Row & Inter-row & Row & Inter-row & $0-5 \mathrm{~cm}$ & $5-20 \mathrm{~cm}$ & & \\
\hline \multicolumn{11}{|c|}{ Manure $\left(\mathrm{Mg} \mathrm{ha}^{-1}\right)$} \\
\hline 0 & $1.39 \mathrm{a}$ & $1.44 \mathrm{a}$ & $6.48 \mathrm{a}$ & $5.27 \mathrm{a}$ & $7.6 \mathrm{a}$ & $6.4 \mathrm{a}$ & $0.34 \mathrm{a}$ & $0.20 \mathrm{a}$ & $13.69 \mathrm{a}$ & - \\
\hline 30 & $1.22 \mathrm{~b}$ & $1.42 \mathrm{a}$ & $14.07 \mathrm{a}$ & $8.48 \mathrm{a}$ & $24.5 b$ & $12.0 \mathrm{~b}$ & $0.40 \mathrm{a}$ & $0.21 \mathrm{a}$ & $26.17 b$ & - \\
\hline 60 & $1.17 \mathrm{c}$ & $1.38 \mathrm{a}$ & $14.62 \mathrm{a}$ & $8.79 a$ & $38.4 \mathrm{c}$ & $23.4 \mathrm{c}$ & $0.75 b$ & $0.20 \mathrm{a}$ & $26.71 b$ & - \\
\hline \multicolumn{11}{|c|}{ Tillage system } \\
\hline$T_{1}^{\mathrm{g}}$ & $1.27 \mathrm{a}$ & $1.41 \mathrm{a}$ & $11.59 \mathrm{a}$ & $7.29 \mathrm{a}$ & $22.7 \mathrm{a}$ & $16.7 \mathrm{a}$ & $0.23 \mathrm{a}$ & $0.12 \mathrm{a}$ & $22.64 \mathrm{a}$ & $43 \mathrm{a}$ \\
\hline$T_{2}{ }^{\mathrm{h}}$ & $1.24 \mathrm{a}$ & $1.42 \mathrm{a}$ & $11.88 \mathrm{a}$ & $7.73 \mathrm{a}$ & $22.0 \mathrm{a}$ & $16.5 \mathrm{a}$ & $0.26 \mathrm{a}$ & $0.09 \mathrm{a}$ & $21.74 \mathrm{a}$ & $30 \mathrm{~b}$ \\
\hline
\end{tabular}

${ }^{a}$ Means with the different letters in each column and each group are significantly different at $P<0.05$.

${ }^{\mathrm{b}}$ Bulk density.

${ }^{\mathrm{c}}$ Saturated hydraulic conductivity.

${ }^{\mathrm{d}}$ Organic matter content.

${ }^{\mathrm{e}}$ Mean weight diameter.

${ }^{\mathrm{f}}$ Dry silage yield.

g Conventional tillage system.

${ }^{\mathrm{h}}$ Reduced tillage system.

tracks (Table 3). Applying 30 and $60 \mathrm{Mg} \mathrm{ha}^{-1}$ manure to the soil decreased soil BD on the row by 12 and $16 \%$, respectively. Other researchers reported similar results of the effect of manure on soil BD (Tairk et al., 1974; Soane, 1990; Felton and Ali, 1992). The mean $\mathrm{BD}$ values for row were significantly less than that for inter-rows (1.26 and $1.41 \mathrm{Mg} \mathrm{m}^{-3}$, respectively). This was due to the effect of manure accumulation and root density on the crop row compared to the inter-row. The OM content and root density (1.5 and $0.03 \mathrm{~cm}$ root length per cubic centimeter soil for row, and inter-row, respectively) in the rows were higher than the inter-row tracks. Root activity can increase porosity and decrease $\mathrm{BD}$.

\subsection{Manure effect on soil hydraulic conductivity}

Due to the high coefficient of variability $(\mathrm{CV})$ values for $\mathrm{K}_{\mathrm{S}}$ (46\% for row, and $80 \%$ for inter-row), the data were normalized as $\log \left(K_{\mathrm{S}}\right)$ (Cosby et al., 1984). Hydraulic conductivity $\left(\log \left(K_{\mathrm{S}}\right)\right)$ was significantly $(P<$ 0.1 ) increased by manure application on both row and inter-row positions. Felton and Ali (1992) and Ohu et al. (1994) reported that adding manure would increase soil hydraulic conductivity. Manure application rates of 30 and $60 \mathrm{Mg} \mathrm{ha}^{-1}$ increased $K_{\mathrm{S}}$ by twofold for row tracks and 1.5-fold for inter-row tracks, respectively. The differences among $K_{\mathrm{S}}$ of manure treatments were remarkable, but the values were not significant at 0.05 level of probability. The reason for this may be due to the large $\mathrm{CV}$. In this study, though the $\mathrm{CV}_{\mathrm{S}}$ decreased after transforming $K_{\mathrm{S}}$ to $\log \left(K_{\mathrm{S}}\right)$, the $\log \left(K_{\mathrm{S}}\right)$ data were not significantly different at $P<0.05$.

Generally, the mean $K_{\mathrm{S}}$ values were significantly higher in the rows than in the inter-rows (1172 and $751 \mathrm{~cm} \mathrm{~h}^{-1}$, respectively). This could be due to the higher effect of manure and root systems on the row tracks. Another reason might be the existence of larger volume of loose soil on the ridges.

\subsection{Manure effect on MWD}

Farmyard manure had a significant effect on MWD (Table 3). Generally, soil organic carbon is a basic factor affecting aggregation stability (Elliott, 1986). Bear et al. (1994) reported that aggregates ranging from 2 to $0.25 \mathrm{~mm}$ in size need to be protected by organic carbon agents otherwise, under heavy and intensive cultivation, the aggregates would be disrupted. Angers and Mehuys (1989) also reported that in clay soil of a humid region applying a no-tillage system resulted in conserving a higher amount of organic carbon and 
more stable aggregates compared to other tillage treatments.

Applying $60 \mathrm{Mgha}^{-1}$ manure to the soil significantly increased MWD at $0-5 \mathrm{~cm}$ depth compared to the other treatments. This effect was not observed at $5-20 \mathrm{~cm}$ depth due to higher soil variability with depth for MWD (Table 3). Mahboubi et al. (1993) indicated that careful selection of sampling sites is essential for obtaining reliable data where varying soil conditions exist in the area to be sampled, for example, where crop rows or ridge tillage is involved. Thus, it is proposed for studying tillage and manure effects on MWD (or soil physical properties), samples should be collected from a shallow soil layer (Hajabbasi and Hemmat, 2000).

\subsection{Manure effect on $D B Y$}

Corn biomass yield increased significantly as a result of manure application. Applying 30 and $60 \mathrm{Mg} \mathrm{ha}^{-1}$ manure to the soil increased DBY by twofold (Table 3).

Manure application improves soil physical properties (Stone and Ekwue, 1995) and provides the necessary plant nutrients and thus increase yield (Meek et al., 1982; Robertson and Erickson, 1978). Soils in central Iran are low in OM $(<1 \%)$ and have poor physical properties, thus adding manure significantly affects plant yield (Afyuni et al., 1998).

\subsection{Tillage effect on the soil properties and DBY}

Tillage systems are site-specific, so the degree of their success depends on soil, climate and management practices. The two tillage systems did not have any significant difference on soil physical properties and DBY (Table 3). This might be due to the higher effect of manure compared to tillage on soil physical properties. In general, soil physical properties are greatly affected by tillage systems immediately or within a short time after tillage, whereas in this study soil samples were collected about 5 months after application of the tillage systems. It can be assumed that after this period the good soil tilth came back to the initial pre-tillage state due to its unstable and fragile structure. In agreement with this result, Hemmat (personal communication) showed that cone index of a clay loam in Isfahan increases and approaches its initial pre-tillage value at the end of growing season. Without tillage practice this soil is compacted and is sensitive to crust formation (Mosaddeghi et al., 2003). Bauer and Black (1981) reported little differences in soil structural characteristics among tillage systems in arid and semi-arid regions due to low precipitation and high temperature that result in a lower potential for soil organic carbon accumulation. After 11 years of study on a sandy loam soil in a semi-arid region, Campbell and Souster (1982) reported that due to equal residue production of systems, neither tillage nor fallow ele-

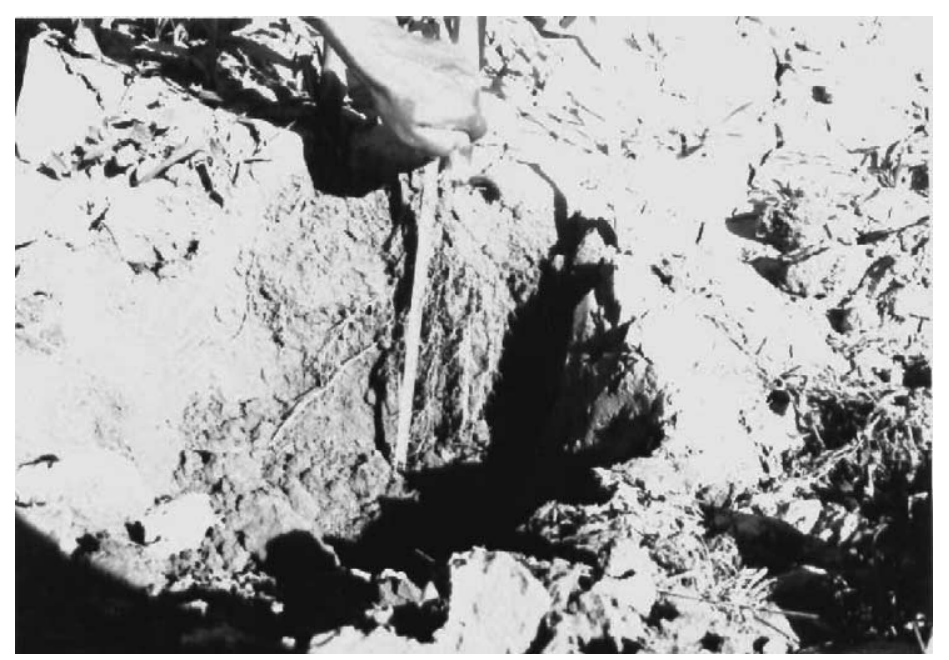

Fig. 1. The effect of moldboard plowing on root depth and distribution. 


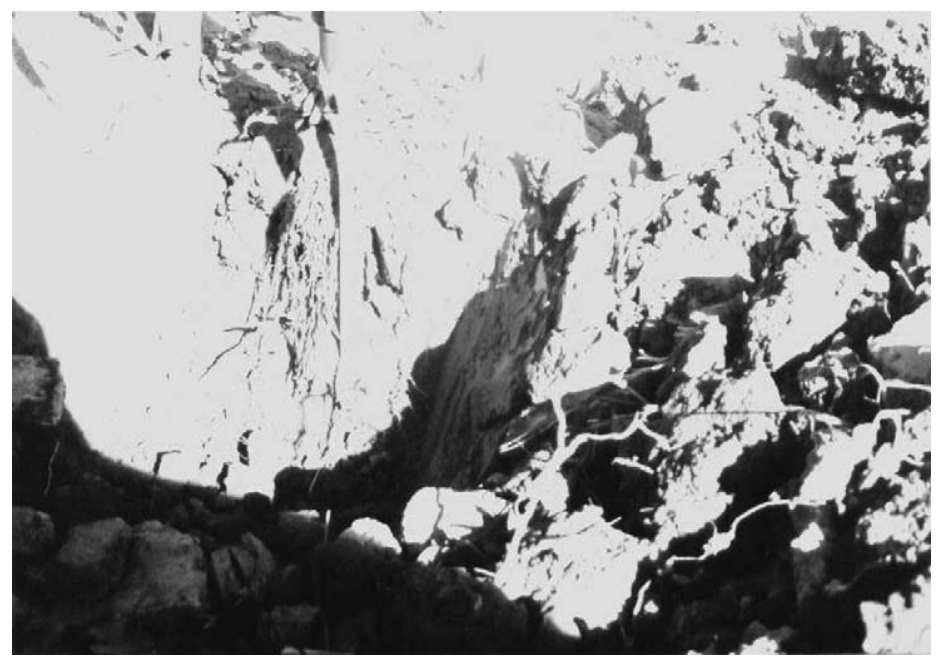

Fig. 2. The effect of disk harrowing on root depth and distribution.

vated soil organic carbon content. Lal (1999) reported that tillage systems (no-till, chisel plowing and moldboard plowing) did not have a significant effect on BD and $K_{\mathrm{S}}$. Also, Lal (1996) indicated that tillage methods had no significant effect on sugarbeet yield. Duiker and Lal (1999) reported that water retention characteristics and pore size distribution were not influenced by tillage system. However, conventional tillage $\left(T_{1}\right)$ increased the depth of root penetration in soil (root depth from row top was about $40 \mathrm{~cm}$ ) in comparison with disk harrowing $\left(T_{2}\right)$ (root depth from row top was about $30 \mathrm{~cm}$ ) (Table 3). In general, conservation and reduced tillage systems favor more root growth in the surface layer (Lal, 1989). The conventional tillage systems decreased soil strength to a greater depth compared to disk harrowing and thus root could penetrate easier in the soil (Figs. 1 and 2).

Although, the tillage systems affected root depth, this did not have any effect on corn biomass yield. This was probably due to the fact that the plant could take up the required nutrients from the upper layer of the soil. It means that irrigated crop was able to obtain the water and essential nutrients from the topsoil in both tillage systems. Another explanation for the lack of yield response to different root depth may be that more roots were produced by the plant than were needed to adequately supply the plant's need for water and mineral nutrients (De Roo, 1968).

\section{Conclusions}

Manure application significantly increased soil OM content on the row and inter-row positions. OM content on the row was higher than that in the inter-row, which shows a higher accumulation and effect of manure on the row tracks. Farmyard manure affected soil physical properties and DBY. Adding manure decreased BD significantly on the row. On the inter-row, due to lower accumulation of the manure, BD was not affected by manure treatments, and its values were significantly higher than the row. Manure application significantly $(P<0.1)$ increased $\log \left(K_{\mathrm{S}}\right)$ in both row and inter-row positions. The differences in $K_{\mathrm{S}}$ values were remarkable, but at 0.05 level of probability the values were not significant. This might be due to the great value of the $\mathrm{CV}$ for $K_{\mathrm{S}}$. The overall means of soil hydraulic conductivities on the row were remarkably higher than inter-row. Manure application at $60 \mathrm{Mg} \mathrm{ha}^{-1}$ increased MWD significantly in $0-5 \mathrm{~cm}$ layer, but did not have any significant effect on MWD at 5-20 cm depth. Corn biomass yield was increased significantly by manure application.

Tillage systems did not have any significant effect on soil physical properties and corn biomass yield. Conventional tillage increased root penetration as compared with disk harrowing. 


\section{Acknowledgements}

The authors would like to thank Isfahan University of Technology for financial support of this study. Also we would like to thank Mr. M.R. Mosaddeghi, Mr. M. Sharifi and Mr. Agharokh, for their help in execution of this research.

\section{References}

Afyuni, M., Rezainejad, Y., Khayambashi, B., 1998. Effect of sewage sludge on yield and heavy metal uptake of lettuce and spinach. J. Agric. Natur. Resour. Sci. Technol. 2, 19-30 (in Farsi with English summary).

Angers, D.A., Mehuys, G.R., 1989. Effects of cropping on carbohydrate content and water-stable aggregation of a clay soil. Can. J. Soil Sci. 69, 373-380.

Bahremand, M.R., Afyuni, M., Hajabbasi, M.A., Rezainejad, Y., 2003. Short and mid-term effects of organic fertilizers on some soil physical properties. J. Agric. Natur. Resour. Sci. Technol. 6 (4) (in Farsi with English summary), (in press).

Bauer, A., Black, A.L., 1981. Soil carbon, nitrogen, and bulk density comparison in two crop land tillage systems after 25 years in virgin grassland. Soil Sci. Soc. Am. J. 45, 1160-1170.

Bear, M.H., Hendrix, P.F., Coleman, D.C., 1994. Water stable aggregates and organic carbon fractions in conventional and no-tillage soils. Soil Sci. Soc. Am. J. 58, 777-786.

Campbell, C.A., Souster, W., 1982. Loss of organic carbon and potentially mineralizable nitrogen from Saskachewan soils due to dropping. Can. J. Soil Sci. 62, 651-656.

Cosby, B.J., Hornbeger, G.M., Clapp, R.B., Ginn, T.R., 1984. A statical exploration of the relationship of soil moisture characteristics to physical properties of soil. Water Resour. Res. 20 (60), 682-690.

De Roo, H.C., 1968. Tillage and root growth. In: Whittington, W.J. (Ed.), Root Growth. Butterworths, London, pp. 339-358.

Duiker, S.W., Lal, R., 1999. Crop residue and tillage effects on carbon sequestration in a Luvisol in central Ohio. Soil Till. Res. 52, 73-81.

Elliott, E.T., 1986. Aggregate structure and carbon, nitrogen and phosphorus in native and cultivated soils. Soil Sci. Soc. Am. J. 50, 627-633.

Felton, G.K., Ali, M., 1992. Hydraulic parameter response to incorporated organic matter in the B horizon. Trans. ASAE 35, $1153-1160$.

Hajabbasi, M.A., Hemmat, A., 2000. Tillage impacts on aggregate stability and crop productivity in a clay-loam soil in central Iran. Soil Till. Res. 56, 205-212.

Hemmat, A., Khashoei, A., 1997. Effects of direct drilling, non-inversion, and conventional tillage systems on yield of irrigated winter wheat. Iran. J. Agric. Sci. 28 (1), 15-30 (in Farsi with English summary), (in press).

Hemmat, A., Taki, O., 2001. Grain yield of irrigated winter wheat as affected by stubble-tillage management and seeding rates in central Iran. Soil Till. Res. 63, 57-64.
Kemper, W.D., Rosenau, R.C., 1986. Aggregate stability and size distribution. In: Method of Soil Analysis. Part 1. Physical and Mineralogical Methods, Soil Science Society of American Agronomy Monograph No. 9, 2nd ed., pp. 425-440.

Klute, A., Dirksen, C., 1986. Hydraulic conductivity and diffusivity: laboratory methods. In: Klute, A. (Ed.), Methods of Soil Analysis. Part 1. Soil Science Society of America, Madison, WI, pp. 687-732.

Lal, R., 1989. Conservation tillage for sustainable agriculture: tropics versus temperate environments. Adv. Agron. 42, 85-197.

Lal, R., 1996. Axle load and tillage effects on crop yields on a Mallic Ochraqualf in northwest Ohio. Soil Till. Res. 37, 143160.

Lal, R., 1999. Soil compaction and tillage effects on soil physical properties of a Mallic Ochraqualf in northwest Ohio. J. Sustainable Agric. 14, 53-65.

Lal, R., Mahboubi, A., Fausey, N.R., 1994. Long-term tillage and rotation effects on properties of central Ohio soils. Soil Sci. Soc. Am. J. 58, 517-522.

Mahboubi, A., Lal, R., Fausey, N.R., 1993. Twenty-eight years of tillage effects on two soils on Ohio. Soil Sci. Soc. Am. J. 57, 506-512.

Meek, B., Graham, L., Donovan, T., 1982. Long-term effects of manure on soil nitrogen, phosphorus, potassium, sodium, organic matter, and water infiltration rate. Soil Sci. Soc. Am. J. 44, 1113-1118.

Mirlohi, A.F., Hajabbasi, M.A., Ghanaati, E., 2000. Tillage effects on yield of six maize genotypes. J. Agric. Natur. Resour. Sci. Technol. 4, 78-87 (in Farsi with English summary).

Mosaddeghi, M.R., Hajabbasi, M.A., Hemmat, A., Afyuni, M., 2000. Soil compactibility as affected by soil moisture content and farmyard manure in central Iran. Soil Till. Res. 55, 87-97.

Mosaddeghi, M.R., Hemmat, A., Hajabbasi, M.A., 2003. Physical and mechanical properties changes of a structurally unstable soil after flood irrigation. J. Agric. Natur. Resour. Sci. Technol. 7 (1) (in Farsi with English summary), (in press).

Ohu, J.O., Ekwue, E.T., Folorunso, O.A., 1994. The effect of addition of organic matter on the compaction of a Vertisol from northern Nigeria. Soil Technol. 7, 155-162.

Qiguo, Z., Hui, C., 2000. Pedosphere and its effect on global change. Pedosphere 10, 97-106.

Robertson, L.S., Erickson, A.E., 1978. Soil compaction, symptoms, causes, remedies. Crop Soils Mag. 1-5.

SAS, 1985. SAS User's Guide: Statistics, 5th ed. SAS Institute Inc., Cary, NC.

Sheldrick, B.H., Wang, C., 1993. Particle size distribution. In: Carter, M.R. (Ed.), Soil Sampling and Methods of Analysis. Lewis Publications/CRC Press, Boca Raton, FL, pp. 499-511.

Soane, B.D., 1990. The role of organic matter in soil compactibility: a review of some particle aspect. Soil Till. Res. 16, 179-201.

Stone, R.J., Ekwue, E.T., 1995. Compressibility of some Trinidadian soils as affected by the incorporation of peat. J. Agric. Eng. Res. 60, 15-24.

Tairk, A.E., Mazurak, A.P., Chesnin, L., 1974. Physical and chemical properties of soil associated with heavy applications of manure from cattle feedlots. Soil Sci. Soc. Am. Proc. 38, $826-830$. 
Thomas, G.W., Haszler, G.R., Blevines, R.L., 1996. The effects of organic matter and tillage on maximum compactibility of soils using the proctor test. Soil Sci. 161, 502508.

Unger, P.W., 1984. Tillage systems for soil and water conservation. FAO Soils Bulletin No. 54, 278 pp.
Unger, P.W., McCalla, T.M., 1980. Conservation tillage systems. Adv. Agron. 33, 1-58.

Walkley, A., Black, I.A., 1934. An examination of the effect of the digestive method for determining soil organic matter and the proposed modification of the chromic acid titration method. Soil Sci. 37, 29-38. 